\title{
Contributions to the research of ecological gradients in the treatment of floristic data (Oran, Algeria)
}

\author{
Mustapha Ainad Tabet, Noury Benabadji, Abdessamad Merzouk* \& Halima Benmoussa \\ ILaboratory of Ecology and Management of Natural Ecosystems, Department of Biology, Faculty of Sciences, University of Abou \\ Bekr Belkaid Tlemcen, BP 119, 13000 Algeria \\ *Corresponding author, email: as_merzouk@yahoo.fr
}

\begin{abstract}
The factorial analysis of the correspondence from the "Minitab" software carried out on the floristic inventoried species at four different stations in Oran region (Algeria) made it possible to highlight interesting information on the numerous ecologic variations which evolve over time in a certain environment. This biostatistical treatment has also revealed a certain number of gradients (environmental disturbances) underlying the different axes of the factorial planes of the stations. These factors are mainly related to anthropogenic actions (crops, nitrates, etc.) which often lead to frequent therophytisation. To these are added other natural factors such as salinity and steppisation.
\end{abstract}

KEY WORDS Multivariate analysis; Ecological factors; Gradients; Algeria.

Received 16.11.2019; accepted 26.02.2020; published online 28.04.2020.

\section{INTRODUCTION}

The pre-forest formations as well as the steppe areas are often exposed to numerous ecologic variations which evolve over time.

For almost a quarter of a century, factorial correspondence analysis (CFA) has been widely used in all areas of ecology, in particular in phytoecology (Bonnin \& Tatoni, 1990). According to these authors, factor analysis of correspondence has been the subject to date of many considerations regarding its use in ecology.

The variables that can intervene are numerous, leading us to perform an interpretation which is essentially based on statistical analysis. Benzekri's (1970) work on factorial correspondence analysis (AFC) has helped to advance it. This analysis is used in particular in phytoecology and phytosociology and was developed by a certain number of authors, among them: Dagnelie (1960, 1965,
1970), Cordier (1965), Gounot (1969), Perrichaud \& Bonnin (1993), Benzekri (1970, 1990), Celles (1975), Chessel \& Bournaud (1987), Loisel et al. (1990), El-Hamrouni (1992), Benabadji et al. (2004), Aboura et al. (2007), and Merzouk (2010).

The method in question individualizes and characterizes plant associations and is the best suited to gather and, above all, to identify the responsible ecological factor (from the most distant species on the axes).

The objective of this study is to try to study the floristic diversity which is governed by ecological factors at the level of some matorral and anthropozoogenic stations that we will try to bring out from this biostatistical approach.

In particular, we studied what are the main ecological variations obtained through the analysis of the factors and what information they can provide in our different geographical stations and on the different factor plans. 


\section{MATERIAL AND METHODS}

\section{Study area}

The study area includes different stations, chosen from a stratified sampling, located in Oran District, Algeria. In particular, this study area is located in the Wilaya of Tlemcen, along the road Tlemcen Maghnia RN 35 (Fig. 1). It extends over an area of $9017.59 \mathrm{~km}^{2}$, rises to an approximate altitude of 214 meters a.s.l. and is between $34^{\circ} 25^{\prime}$ and $35^{\circ} 25^{\prime}$ north latitude and $0^{\circ} 55^{\prime}$ and $2^{\circ} 30^{\prime}$ west longitude.

The study area choice was guided by the presence of halophyte plant formations. Four stations were stratified, which may seem insufficient in a territory spanning such a large area.

The statistical processing from the "Minitab 16 " software took into account the plant species after having coded them for readings from each station. We then placed them in a table in Excel (with the statements in rows and the species in columns).

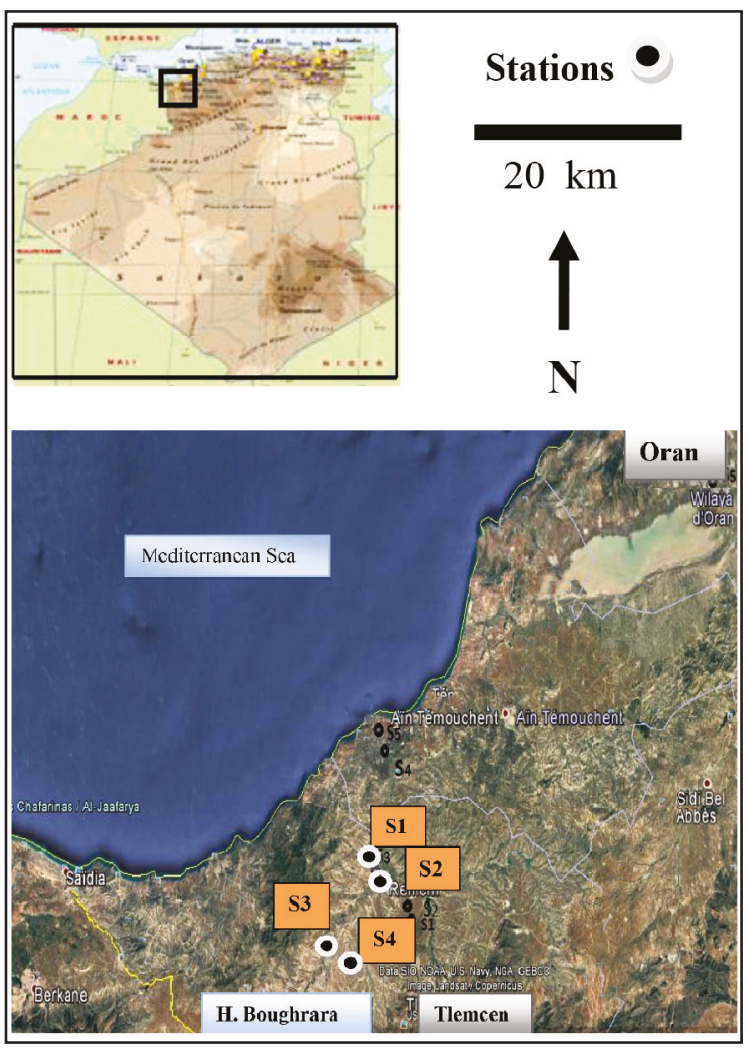

Figure 1. The study area.
One of the fundamental interests of this method is the simultaneous representation in the same space and in a symmetrical way of the surveys and the species so that each species is localized within the group of surveys to which it is most closely linked to (Lacoste, 1972).

Only the abundance-dominance coefficient is used. The tables constitute the matrix from which the distance calculations are made.

\section{RESULTS AND DISCUSSION}

Station 1 (Figs. 2, 3, Tables 1-4)

\section{Axis 1}

We notice a large central grouping with species of weak ecological significance. An increasing postcultural gradient that goes from the positive side to the negative side of the axis. We also noticed an increasing gradient of salinity going from the negative side to the positive side.

\section{Axis 2}

Here too, a large central groups together species with weak ecological significance. An increasing pre-forest/scrub gradient (Asparagus albus -2.00862) which goes from the positive side to the negative side of the axis. We also notice an increasing crop gradient (Phalaris bulbosa +2.36252 ) going from the negative side to the positive side of the axis.

\section{Axis 3}

An increasing xericity gradient, presence of thorny species (Eryngium tricuspidatum -2.93640) which goes from the positive side to the negative side of the axis. We also notice an increasing grazing gradient going from the negative side to the positive side of the axis.

Station 2 (Figs. 4, 5, Tables 5-8)

\section{Axis 1}

An increasing matorral gradient (Echium pycnanthum -2.359) is well signified which goes from the positive side to the negative side of the axis. On 


\begin{tabular}{|l|c|c|c|}
\hline stations & Axis 1 & Axis 2 & Axis 3 \\
\hline own value & 1.4720 & 0.8901 & 0.6379 \\
\hline inertia & 0.491 & 0.297 & 0.213 \\
\hline
\end{tabular}

Table 1. Station 1: inertia and eigenvalue of the axes.

\begin{tabular}{|l|l|}
\hline \multicolumn{1}{|c|}{ Negative side } & \multicolumn{1}{c|}{ Positive side } \\
\hline Phalaris bulbosa $(-2.91336)$ & Atriplex halimus $(+0.52104)$ \\
Plantago psyllium & Calycotome spinosa \\
$(-2.35990)$ & $(+0.52104)$ \\
\hline
\end{tabular}

Table 2. Station 1, axis 1: coordinates species.

\begin{tabular}{|l|l|}
\hline \multicolumn{1}{|c|}{ Negative side } & \multicolumn{1}{c|}{ Positive side } \\
\hline Asparagus albus $(-2.00862)$ & Phalaris bulbosa $(+2.36252)$ \\
Plantago ovata $(-2.00862)$ & Chrysanthemum \\
Ceratocephalus faluatus & grandiflorum $(+1.80770)$ \\
$(-2.91336)$ & \\
\hline
\end{tabular}

Table 3. Station 1, axis 2: coordinates species.

\begin{tabular}{|l|l|}
\hline \multicolumn{1}{|c|}{ Negative side } & \multicolumn{1}{c|}{ Positive side } \\
\hline $\begin{array}{l}\text { Eryngium tricuspidatum } \\
(-2.93640)\end{array}$ & $\begin{array}{l}\text { Phalaris bulbosa } \\
(+1.15983)\end{array}$ \\
\hline
\end{tabular}

Table 4. Station 1, axis 3: coordinates species.

the other hand, we notice an increasing gradient of salinity (Atriplex halimus +0.52104 ) going from the negative side to the positive side.

\section{Axis 2}

An increasing gradient after the use of crops (Avena sterilis -2.00862) going from the positive side to the negative side of the axis. The other side is characterized by an increasing gradient of overgrazing (Plantago ovata +2.36252 ) going from the negative side to the positive side.

\section{Axis 3}

An increasing salinity gradient (Stipa tortilis -2.93640) which goes from the positive side to the negative side of the axis. The other side is marked by an increasing gradient of matorral (Echium pycnanthum +2.78060 ) going from the negative side to the positive side.

Station 3 (Figs. 6, 7, Tables 9-12)

\section{Axis 1}

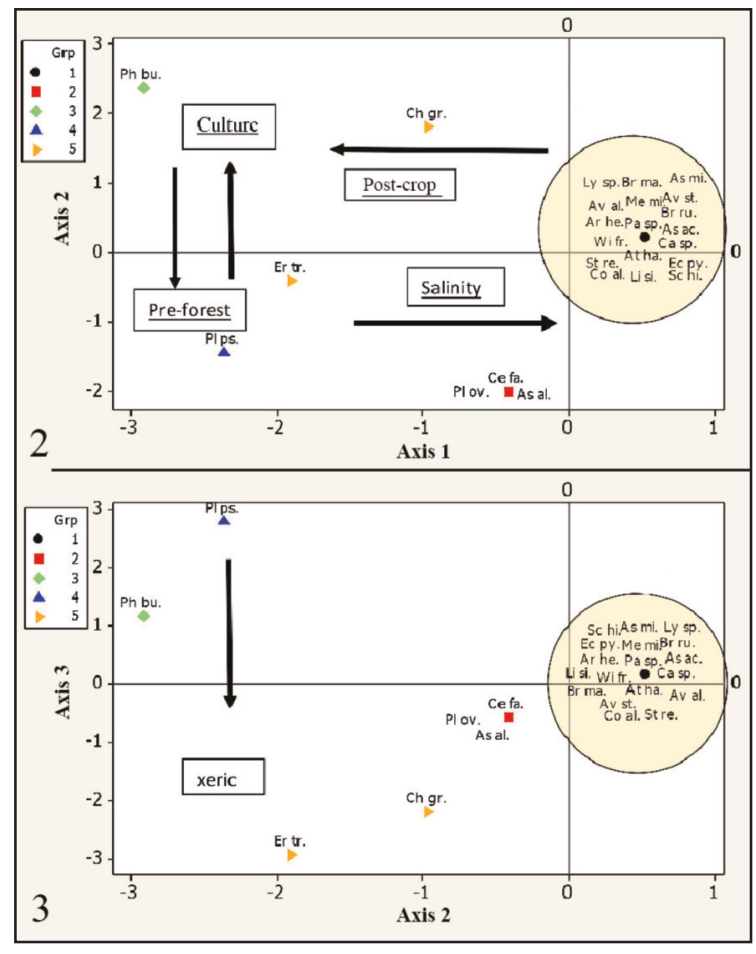

Figure 2. Factorial plan of species Station 1 (Axis 1-Axis 2). Figure 3. Factorial plan of species Station 1 (Axis 1-Axis 3).

An increasing nitrates gradient (Phalaris bulbosa, Medicago falcata -1.64018) which goes from the positive side to the negative side of the axis. On the opposite side of the axis an increasing Steppe gradient (Artemisia herba-alba +1.13202 ) appears going from the negative side to the positive side.

\section{Axis 2}

An increasing salinity gradient (Atriplex halimus -0.98141) which goes from the positive side to the negative side of the axis. The positive side is marked by an increasing gradient of $\mathrm{CaSO} 4$ (Lygeum spartum +1.88103 ) and anthropization (Plantago ovata / culture +1.85169 ) going from the negative side to the positive side.

\section{Axis 3}

An increasing post-cultural gradient (Bromus rubens -2.38129 ) which goes from the positive side to the negative side of the axis. On the positive side an increasing gradient of overgrazing (Ziziphus lotus +1.76932 ) going from the negative side to the positive side. 


\begin{tabular}{|l|c|c|c|}
\hline stations & Axis 1 & Axis 2 & Axis 3 \\
\hline own value & 1.4623 & 1.1875 & 0.3501 \\
\hline inertia & 0.487 & 0.396 & 0.117 \\
\hline
\end{tabular}

Table 5. Station 2: inertia and eigenvalue of the axes.

\begin{tabular}{|l|l|}
\hline \multicolumn{1}{|c|}{ Negative side } & \multicolumn{1}{c|}{ Positive side } \\
\hline $\begin{array}{l}\text { Echium pycnanthum } \\
(-2.35990)\end{array}$ & $\begin{array}{l}\text { Atriplex halimus }(+0.52104) \\
\text { Withania frutescens } \\
(+0.52104)\end{array}$ \\
\hline
\end{tabular}

Table 6. Station 2 axis 1: coordinates species.

\begin{tabular}{|l|l|}
\hline \multicolumn{1}{|c|}{ Negative side } & \multicolumn{1}{c|}{ Positive side } \\
\hline Avena sterilis $(-2.00862)$ & Plantago ovata $(+2.36252)$ \\
Linaria simplex $(-2.00862)$ & \\
Pisum sativum (-2.00862) & \\
\hline
\end{tabular}

Table 7. Station 2 axis 2: coordinates species.

\begin{tabular}{|c|l|}
\hline Negative side & \multicolumn{1}{|c|}{ Positive side } \\
\hline Stipa tortilis $(-2.93640)$ & $\begin{array}{l}\text { Echium pycnanthum } \\
(+2.78060)\end{array}$ \\
\hline
\end{tabular}

Table 8. Station 2 axis 3: coordinates species.

\begin{tabular}{|l|c|c|c|}
\hline stations & Axis 1 & Axis 2 & Axis 3 \\
\hline own value & 1.5671 & 0.4450 & 0.9878 \\
\hline inertia & 0.522 & 0.329 & 0.148 \\
\hline
\end{tabular}

Table 9. Station 3: inertia and eigenvalue of the axes.

\begin{tabular}{|l|l|}
\hline \multicolumn{1}{|c|}{ Negative side } & \multicolumn{1}{c|}{ Positive side } \\
\hline $\begin{array}{l}\text { Phalaris bulbosa (-1.64018) } \\
\text { Medicago falcate (-1.64018) }\end{array}$ & $\begin{array}{l}\text { Artemisia herba-alba } \\
(+1.13202)-\text { Asparagus } \\
\text { acutifolius }(+1.13202)\end{array}$ \\
\hline
\end{tabular}

Table 10. Station 3, axis 1: coordinates species.

\begin{tabular}{|c|l|}
\hline \multicolumn{1}{|c|}{ Negative side } & \multicolumn{1}{c|}{ Positive side } \\
\hline Atriplex halimus $(-0.98141)$ & $\begin{array}{l}\text { Lygeum spartum } \\
(+1.88103)\end{array}$ \\
& $\begin{array}{l}\text { Plantago ovata } \\
(+1.85169)\end{array}$ \\
\hline
\end{tabular}

Table 11. Station 3, axis 2: coordinates species.

\begin{tabular}{|l|l|}
\hline \multicolumn{1}{|c|}{ Negative side } & \multicolumn{1}{c|}{ Positive side } \\
\hline $\begin{array}{l}\text { Bromus rubens }(-2.38129) \\
\text { Eryngium tricuspidatum }\end{array}$ & $\begin{array}{l}\text { Ziziphus lotus }(+1.76932) \\
\text { Avena alba }\end{array}$ \\
\hline
\end{tabular}

Table 12. Station 3, axis 3: coordinates species.

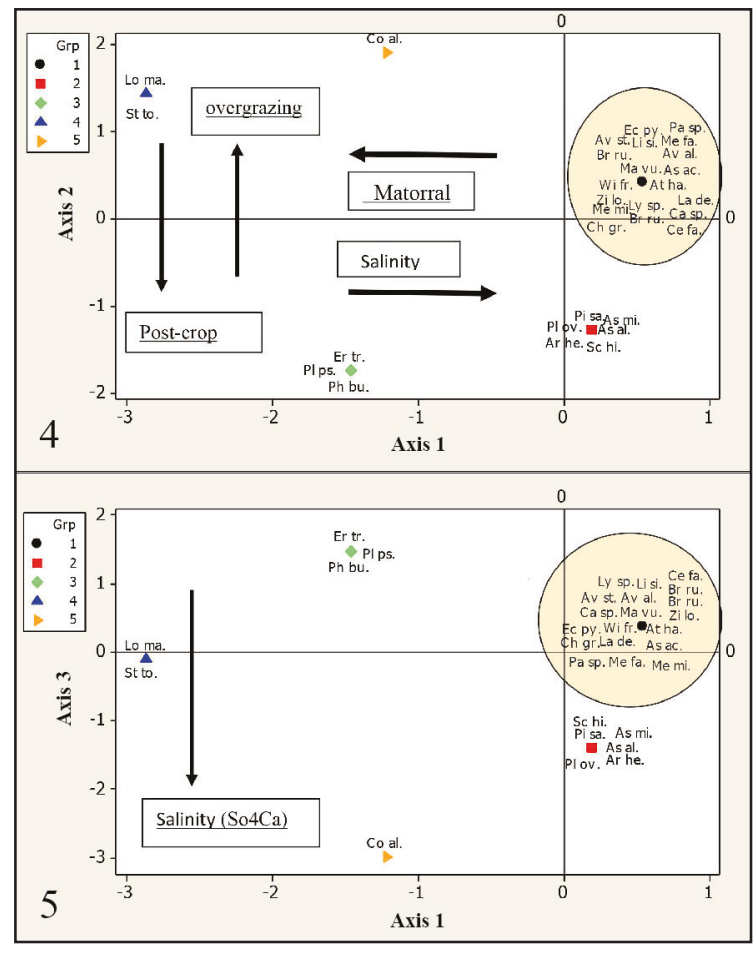

Figure 4. Factorial plan of species Station 2 (Axis 1-Axis 2). Figure 5. Factorial plan of species Station 2 (Axis 1-Axis 3).

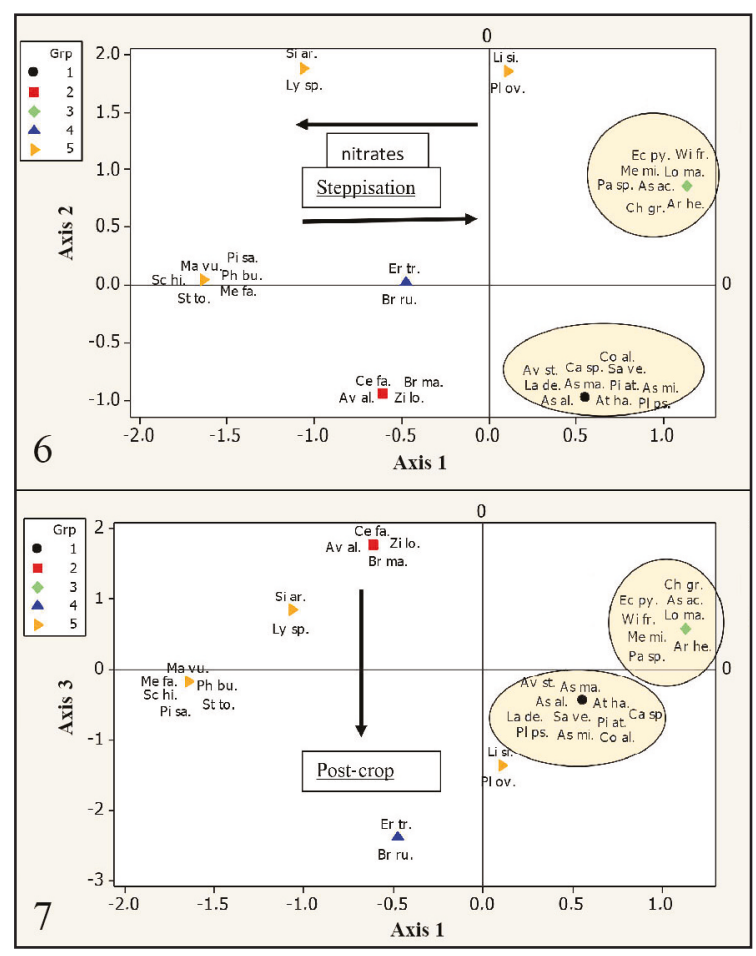

Figure 6. Factorial plan of species Station 3 (Axis 1-Axis 2). Figure 7. Factorial plan of species Station 3 (Axis 1-Axis 3). 
Station 4 (Figs. 8, 9, Tables 13-16)

\section{Axis 1}

An increasing gradient of grazed steppe (Artemisia herba-alba -1.69176) which goes from the positive side to the negative side of the axis. An increasing gradient of pre-forest (Asparagus albus +1.51572 ) exists which goes from the negative side to the positive side.

\section{Axis 2}

An increasing saline steppe gradient (Atriplex halimus and Withania frutescens -1.06156) which goes from the positive side to the negative side of the axis. An increasing gradient of pre-forest exists which goes from the negative side to the positive side.

\section{Axis 3}

An increasing lawn gradient (Echium pycanthum and Bromus madritensis -1.69551) which goes from

\begin{tabular}{|l|c|c|c|}
\hline stations & Axis 1 & Axis 2 & Axis 3 \\
\hline own value & 1.1759 & 0.9958 & 0.8283 \\
\hline inertia & 0.392 & 0.332 & 0.276 \\
\hline
\end{tabular}

Table 13. Station 4: inertia and eigenvalue of the axes.

\begin{tabular}{|l|l|}
\hline \multicolumn{1}{|c|}{ Negative side } & \multicolumn{1}{c|}{ Positive side } \\
\hline Artemisia herba-alba & Asparagus albus $(+1.51572)$ \\
(-1.69176) - Asparagus & Plantago psyllium \\
acutifolius $(-1.69176)$ & $(+1.51572)$ \\
\hline
\end{tabular}

Table 14. Station 4 axis 1: coordinates species.

\begin{tabular}{|l|l|}
\hline \multicolumn{1}{|c|}{ Negative side } & \multicolumn{1}{c|}{ Positive side } \\
\hline Atriplex halimus & Asphodelus microcarpus \\
$(-1.06156)$ & $(+1.83578)$ \\
Withania frutescens & Lobularia maritima \\
$(-1.06156)$ & $(+1.83578)$ \\
\hline
\end{tabular}

Table 15. Station 4 axis 2: coordinates species.

\begin{tabular}{|l|l|}
\hline \multicolumn{1}{|c|}{ Negative side } & \multicolumn{1}{c|}{ Positive side } \\
\hline Echium pycanthum & Avena sterilis $(+2.11660)$ \\
(-1.69551) - Bromus & Stipa tortilis $(2.11660)$ \\
madritensis $(-1.69551)$ & \\
\hline
\end{tabular}

Table 16. Station 4 axis 3: coordinates species. the positive side to the negative side of the axis. An increasing gradient of pre-forest exists which goes from the negative side to the positive side.

\section{CONCLUSIONS}

This peculiarity of seeing the species of the scrub mixed between them can be perplexing but the factorial treatment was able to partially elucidate on this distribution of undiversified plant formations.

It should be noted that the large area appearing in the middle of the axes includes companion species or with feeble ecological significance.

These treatments, among others by factorial analysis of correspondences on the four stations (with contiguous plots), highlight the classic factors that can characterize these open environments where various species can interfere, as those of the scrub (Asparagus albus, Asparagus acutifolius, Withania frutescens, Pistacia atlantica, Ziziphus lotus, Calycotome spinosa, Lavandula dentata), those of the steppes (Lygeum spartum) and those of
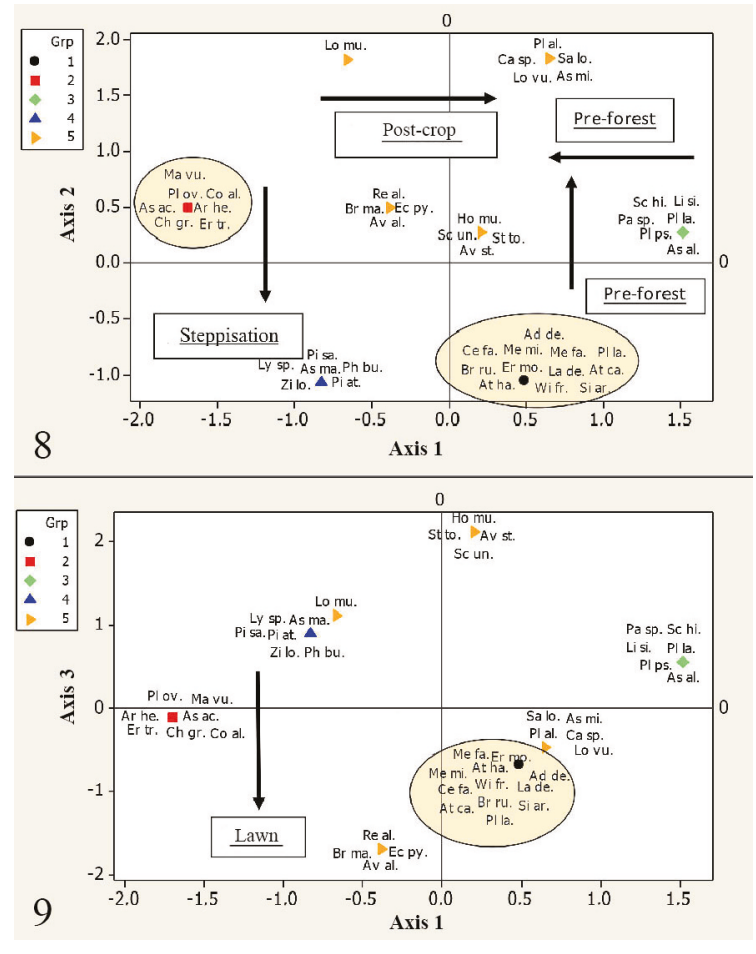

Figure 8. Factorial plan of species Station 4 (Axis 1-Axis 2). Figure 9. Factorial plan of species Station 4 (Axis 1-Axis 3). 
the salty steppes composed of halophilic or halophyte species (Atriplex halimus and Salsola vermiculata in particular).

The biotic and abiotic factors, also called gradients in the ecological sense of the term, are often linked to the multiple actions (disturbances) which are exerted on the ecosystem and that seem obvious at least in our case: overgrazing, culture, matorral, salinity, nitrate, xericinity.

In our opinion, it is useful to complete this study by looking for other ecological factors that can be elucidated from factorial axes on other stations and which can improve the understanding of these natural phenomena.

\section{REFERENCES}

Aboura R., Benmansour D. \& Benabadji N., 2007. Comparaison et phytoécologie des Atriplexaies en Oranie (Algérie). Revue Internationale d'Ecologie Méditerranéenne, 32: 73-84.

Benabadji N., Bouazza M., Merzouk M. \& Ghezlaoui S.M., 2004. Aspects phytoécologiques des Atriplexaies au Nord de Tlemcen (Oranie, Algérie). Revue scientifique et technique, 22: 62-79.

Benzecri J.P., 1970. L'analyse des données. Tome 1. La taxonomie. Edition Dunod. Paris, 675 pp.

Benzecri J.P., 1990. L'analyse des données. Tome 2. L' analyse des correspondances. Edition Dunod, Paris, 619 pp.

Bonnin G. \& Tatoni T., 1990. Réflexions sur l'apport de l'analyse factorielle des correspondances dans l'étude des communités végétales et de leurs environnements. Ecologia Mediterranea, 16: 403-414.

Celles J.C., 1975. Contribution à l'étude de la végétation des confins Saharo-Constantinois (Algérie). Thèse Doctorat University Nice, 364 pp.
Chessel D. \& Bournaud M., 1987. Progrès récents en analyse des données écologiques. Coll. AFIE: La gestion des systèmes écologiques, Bordeaux, pp. 6576.

Cordier B., 1965. L'analyse factorielle des correspondances. Thèse Spécialité Université Rennes, 66 pp.

Dagnelie P., 1960. Contribution à l'étude des communautés végétales par l'analyse factorielle. Bulletin du Service de la carte phytogéographique, Série B: 93195.

Dagnelie P., 1965. L'étude des communautés végétales par l'analyse statistique des liaisons entre les espèces et les variables écologiques, principes fondamentaux un exemple biométrique 21: 345-361 et 890-907.

Dagnelie P., 1970. Théories et méthodes statistiques. Vol. 1 et 2, Faculté Gembloux, 415 pp.

El-Hamrouni A., 1992. Végétation forestière et préforestière de la Tunisie: Typologie et éléments pour la gestion. Thèse. Doctorat. Es. Sciences Université, Aix Marseille III. 220 pp.

Gounot M., 1969. Méthode d'étude quantitative de la végétation. Edition Masson \& Cie, Paris, 314 pp.

Lacoste A., 1972.-La végétation de l'étage sub- alpin du bassin supérieur de la Tigne (Alpes Maritimes) thèse de doctorat, Université de Paris sud. Centre d'Orsay $295 \mathrm{pp}$.

Loisel R., Gamila H. \& Rolando Ch., 1990. Déterminisme écologique de la diversité des pelouses dans la plaine de la Crau (France méridionale). Volume Jubilaire du Prof. Quezel. Ecologie Méditerranée XVI, Marseille: 255-265. Issn : 0153-8756, 1990

Merzouk A., 2010. Contribution à l'étude phytoécologique et biomorphologique des peuplements halophiles dans la région occidentale de l'Oranie. Thèse Doctorat Université Tlemcen, 277 pp.

Perrichaud L. \& Bonnin G., 1973. L'analyse des correspondances appliquées aux groupements végétaux d'altitude du Gran Sasso d'Italie. Notiziario della società italiana di Fitosociologia, 7: 29-43. 